University of Nebraska - Lincoln

DigitalCommons@University of Nebraska - Lincoln

Agronomy \& Horticulture - Faculty Publications

Agronomy and Horticulture Department

2003

\title{
Genetic and Environmental Effects on Dough Mixing \\ Characteristics and Agronomic Performance of Diverse Hard Red Winter Wheat Genotypes
}

\author{
Hikmet Budak \\ University of Nebraska-Lincoln, hbudak4@unl.edu \\ P. Stephen Baenziger \\ University of Nebraska-Lincoln, pbaenziger1@unl.edu \\ Robert A. Graybosch \\ University of Nebraska-Lincoln, bob.graybosch@ars.usda.gov \\ B. S. Beecher \\ University of Nebraska-Lincoln \\ Kent M. Eskridge \\ University of Nebraska-Lincoln, keskridge1@unl.edu
}

See next page for additional authors

Follow this and additional works at: https://digitalcommons.unl.edu/agronomyfacpub

Part of the Plant Sciences Commons

Budak, Hikmet; Baenziger, P. Stephen; Graybosch, Robert A.; Beecher, B. S.; Eskridge, Kent M.; and Shipman, M. J., "Genetic and Environmental Effects on Dough Mixing Characteristics and Agronomic Performance of Diverse Hard Red Winter Wheat Genotypes" (2003). Agronomy \& Horticulture -- Faculty Publications. 595.

https://digitalcommons.unl.edu/agronomyfacpub/595

This Article is brought to you for free and open access by the Agronomy and Horticulture Department at DigitalCommons@University of Nebraska - Lincoln. It has been accepted for inclusion in Agronomy \& Horticulture -Faculty Publications by an authorized administrator of DigitalCommons@University of Nebraska - Lincoln. 


\section{Authors}

Hikmet Budak, P. Stephen Baenziger, Robert A. Graybosch, B. S. Beecher, Kent M. Eskridge, and M. J. Shipman 


\title{
Genetic and Environmental Effects on Dough Mixing Characteristics and Agronomic Performance of Diverse Hard Red Winter Wheat Genotypes ${ }^{1}$
}

\author{
H. Budak, ${ }^{2}$ P. S. Baenziger, ${ }^{23}$ R. A. Graybosch, ${ }^{4}$ B. S. Beceher, ${ }^{2}$ K. M. Eskridge, ${ }^{5}$ and M. J. Shipman ${ }^{2}$
}

\section{ABSTRAC'T}

Wheat (Triticum erstirum I..) genotypes with shor mixing times usually have low mixing tolerance values, which make them more sensitive oovermixing in commereial bread produetion. In this study, we craluated the genotypic and environmental effects on agronomic performance and end-use quality of 27 experimental genotypes (hereafter referred 10 its mixing tolerant genolypes) which were identified in an initial screen as having short mixing times and good mixing tolerances to 1) detemine whether genotypes identified in a preliminaty end-use quility screen as lines with ustally long tolerances but short mixing limes were due to their genotype (G), the enviromment (b), or G $\times$ Fa and ats these results were unusual, 2) determine whether or not our initial sereen predicts end-usc (utality, and 3) determine the stability of both agronomic and end-use quality trats. The 27 genotypes and five check cullivals were grown in a randomized complete block desion with two replicales in nine environments in 1997 and 1998. All plots were harvested for grain yield. The harvested grain from the first replicate and randem ecenotypes from the second replicate were micromilled to

produce flour samples for evaluation of l'lour yield, protein content, and mixograph mixing time and mixing dolerance values. Seed dianeter, thousand kennel weight, and kernel hadness were also measured in three environments. Environment, $\mathrm{G}$, and $\mathrm{G} \times \mathrm{F}$; interaction eflects (mainly changes in magnitude) were significant for most agronomic and end-use quality parameters. Our initial screen, which had identified 27 genotypes, was partially elfective in identifying genotypes that have shorter mixing time values compared with their mixing tolerance values. We identified four genotypes (15\%) from the mixing tolerant genotypes that hat a good mixing tolerance value and relatively shorter mixing lime, as did the released cultivars 'Agate' and 'Scont 66'. I fowever, mixing characteristics values of all genotypes fell within the acceptable limits, indieating our sereen effectively identified genotypes with aceptable guality. Mixing tolerant genotypes, which had been identified as having short mixing time scores and long mixing tolerance scores, were considered stable across enviromments.

Dough mixing properties are very imporlant in breadmaking, and flours milled from different wheat (Triticum aestivam $\mathrm{L}$.) cullivars can vary widely in the work and energy input required for optimum dough development. The fundamental reasons for these differences are not fully understood, however it is believed that protein content and interactions are involved in the dilfercnecs between cultivars (Bushuk 1998). Bread doughs should be mixed to the point of optimum gluten development to produce good bread. More or less mixing caluses improper dough development, which produces an inferior (quality bread (Doenry 1995). An important factor allecting dough quality is the dough mixing time. Dough mixing lime refers to the amount of time required to nix the ingredients to form dough, which deternines the energy consumed by dough mixers. To reduce energy costs, bakers would like short mixing lours. However, llours with short mixing time often have low mixing tolerance values, which means they can be readily overmixed. Overmixing oceurs when the ingredients are added or doughs are mixed beyond the optimal mixing time. Overmixing first results in dough breakdown and products made from overmixed doughs are inferior (Bushuk 1998), even when the best flour is used (Paredes-Loper and Bushuk 1983). The practical advantage of a wheat cultivar that is milled to make a flour with a shorter dough mixing peak time (an indication of optimum dough development and stability) but with good mixing bolerance (an indicator of the resistance of a dough to overmixing) is that less labor, dine, and energy are needed in the bakery to develop the optimum dough, and that the resultant dough is tolerant of overmixing, thus improving consistency of the final product.

In a preliminary screening of wheal germplasm within the Nebraska breeding program in 1996, a number of genotypes were ickntified that had shorter mixing times relative to mixing toler-

\footnotetext{
${ }^{1}$ Contribution of the (Iniversity of Neluastia Agrieulumal Reseateh Division as Jominal Series l'aper No. 13925.

1)epartment of Agronomy \& I lorticulure. Iniversity of Nobraska, Lincoln, NE

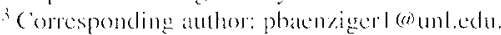

I (SI)A-ARS, Jniversily ol" Nebraska, I incoln, NI:

1) epartment of liometry, University of Nebraski, Lincoln, Nt:
}

ance values. Mixing time is scored as time (min) to peak dough development. Mixing tolerance is scored on a 0 -.7 scale (Nebraska Wheat Quality Lab, Lincoln, NE), taking into account both curve width after peak development and the angle of departure (Bacnziger et al 2001). While mixing time and mixing tolerance are measured in different units, the numerical values (not units) for mixing time in winter wheat tend to correlate with those of mixing tolerance, and it is very rare that the numerical value for mixing tolerance is greater than the numerical value for mixing time. Historically, winter wheat cultivars with good mixing tolerance values have very strong, long mixing time characteristics (Baenziger et al 2001 ). As this was a preliminally screen from one environnent, the shont mixing time charateristic coupled with the good mixing tolerance value could have been due to the cnvironment (E) as well ats the genotypes (G). Though impossible to measure in one environment, it is known that end-use quality characteristics are influeneed by genotypic and environmental factors and their interactions $(\mathrm{G} \times \mathrm{E}$ ) (Peterson et al 1992). For many quality characteristics, environmental varianees were generally larger than those due to genetics (Graybosch et al 1996).

The objectives of this study were to 1) determine whether genotypes identified in a preliminary end-use quality sereen as having mixing time values smaller than mixing tolerance values were due to $\mathrm{G}$, E, or $\mathrm{G} \times \mathrm{L}$; and als these results were unusual 2) determine whether or not our initial sereen predicts end-use quality; and 3 ) determine the stability of both agronomic and end-use quality rails.

\section{MATERIALS AND METHODS}

\section{Plant Materials}

Thirty-two hard red winter what genotypes including 27 13derived 15 genotypes from diverse crosses that had mixing tolerance values greater than the mixing time values in preliminary testing of grain that were hatrvested in 1996 at Lincoln, NE, and live check cultivars ('Agate', 'Arapahoe', 'Centura', 'Scout 66', and 'Siouxland') were used in this study. The genolypes were grown at the following Nebraska locations: Lincoln (1997), Clay Center (1997), North Platte (1997 and 1998), Alliance (1997), Sidncy (1997 and 1998), and Mead (1997 and 1998). These locations are 
representative of diverse Nebraska wheat production areas (Peterson 1992). The genolypes were planted in a randomized complete block design with two replicates using recommended cultural practices. Each genotype was planted in a four-row plot that was $2.4 \mathrm{~m}$ long with $30 \mathrm{~cm}$ between rows.

\section{Agronomic Performance Measurements}

Grain yicld was measured by harvesting the middle two rows at Lincoln and Mead, and harvesting all four rows at Clay Center, North Platte, Alliance, and Sidncy of both replicates. Grain volume weight was measured on a 200 - $\mathrm{mL}$. sample with a volumetric seale (Scedburo Equibment Co., Chicago, IL) at Lincoln (1997), Clay Center (1997), North Platte (1997), Alliance (1997), Sidney (1997), and Mead (1997 and 1998) using first replicate, and a few random lines from the second replicate. Thousand-kernel weight and seed diameter were measured using the Single Kernel Characterization System (SKCS 4100, Perten Instruments, Springfield, II.). SKCS analysis was performed on three samples of 100 seeds each at North Platte (1998), Mead (1998), and Sidney (1998).

\section{End-Use Quality Analysis}

Grain samples $(35 \mathrm{~g})$ from each plot were tempered to a moisture basis of $15.2 \%$ and milled on a Brabender Quadraplex experimental mill (South Hackensack, NJ). Flour was separated from bran using a shaker (Strand, Minneapolis, MN) at $225 \mathrm{rpm}$ for $90 \mathrm{sec}$ with a U.S. Standard Sieve No. 70 and weighed to estimate flour yicld. Flour mixing characteristics were cvaluated using a 10-g mixograph (National Mfg. Co., Lincoln, NE) according to Approved Method 54-40) (AACC 20(00) with absorption of $0.6 \mathrm{~mL}$ of $\mathrm{H}_{2} \mathrm{O} / \mathrm{g}$ of flour. Mixing time was measured as the minutes required to reach fullpeak development. Mixing tolerance was rated subjectively on a 0 7 scale (Nebraska Wheat Quality Lab, Lincoln, NE), taking into account both curve width alter peak dough development and angle of departure, ranging from very low $(0)$ to very high tolerance (7) of the dough to mixing. Wheat lines with a mixing time of $>3$ min (preferably higher), and mixing tolerance scores of $>3$ (preferably higher) are considered as having acceptable end-use quality (Baenriger et al 2001 ).

Hour protein concentration was determined on a $14 \%$ flour moisture basis using the Udy dye-binding method (Approved Method 46-14A) and periodically verilied with $14 \%$ flour moisture basis using a Leco $\mathrm{N}$ analysis (Approved Method 46-30) by the Soil Analytical Laboratory, Department of Agronomy and Horticulture, University of Nebraska, Lincoln. Kernel hardness was analyzed by SKCS 4100 on the same samples used to measure 1,000 kernel weight and seed diameter.

\section{Statistical Analysis}

Analyses of variance were calculated consialering each localionyear as a separate enviromment using PROC GIMM (SAS' Institulc, Cary, NC). Homogeneity ol variance test was conducted lo determine whether error variances were homogenous across environments and, if so, data from individual enviromments (Ji) Wete pooled to evaluate $\mathrm{G} \times \mathrm{F}$ interations from a combined $\triangle N O \mathrm{~V} A$ across enviromments. Environments were considered as random effects in the combined analysis, whereas genotypes were trealed as a fixed effect. Data for each trait were analyoed for normality using PROC UNIVARIA'tE (SAS). For agronomic taits, all ol the plot data were used. For the end-use quality trats, flour from every genotype from the first replicate was used. and flour of 15 . 20 randomly selected genotypes from the second replicate was used to estimate variation. Historically, the coellicient of variation for most microquality analyses from a laudom subsample ol genotypes in the second replicate wats representative of the vartation from the complete replicate (Baenriger et al 200) l). Single degree of freedom (dl) contrasts were perfomed lor check cultivars versus mixing tolerant genotypes. Hour protein content was used as a covariate to help explain mixing lime and mixing tolerance because wheat flour protein content is correlated to mixing time and mixing tolerance (Graybosch et al 1996).

To evaluate our initial sereen, we looked at genolypes identified with mixing time values smaller than mixing tolerance values 10 see whether these values were within the alceptable limits in ofluer environments. Acceptability wals established for genolypes by choosing absolute limits for each of the live quality raits to reflect the needs and perspective of the milling and baking industry. A genotype was considered aceptable for an individual trat il the value for that trait fell within these established bounds. Values chosen for upper and lower limits were flour protein $12.5 .19 .0 \%$. mixing time 3.5-8.0 min, mixing tolerance 2.5.7.0 (0) a 0 () 7 scale), flour yield $500-650 \mathrm{~g} / \mathrm{kg}$, kernel hardness $250.5 \mathrm{SKCS}$ unit. A line's chance of falling within acceptable limits was calculated using univariate (Eskridge and Mumm 1992) and multivariate (Eskridge el al 1994) probabilities. Probabilities were calculated as a proportion of locatioms that met aceptatility limits for each trait separatcly and all traits smilarly. In practice, our selected genolypes are expected to have consistent mixing times of $>3$ min and mixing tolerance seores of $>3$.

Stability parameters (Eberhart and Russell 1906) were estimated by regressing genotype means on an environmental index. The environmental index was estimated as the mean of all genotypes at a specific environment minus the grand mean. The $b-$ values were tested for the diflenences from $b=1.0$ by at $t$-test. $A$ line was considered stable if $b_{i}=1$.0. The deviations liom the

TABLE I

Mean Square (MS) Values for Combined Analysis of Variance Across Nine Environments in the 1997-1998 Crop Seasons in Nebraska

\begin{tabular}{|c|c|c|c|c|c|c|c|c|c|c|c|c|c|c|}
\hline \multirow[b]{2}{*}{ Source $^{b}$} & \multicolumn{2}{|c|}{$\begin{array}{c}\text { Grain Yield } \\
\text { (kg/ha) }\end{array}$} & \multicolumn{2}{|c|}{$\begin{array}{l}\text { Grain Vol. Wt. } \\
\quad(\mathrm{kg} / \mathrm{hL})\end{array}$} & \multicolumn{2}{|c|}{$\begin{array}{c}\mathrm{TKW}^{\mathrm{a}} \\
(\mathrm{g})\end{array}$} & \multirow{2}{*}{$\begin{array}{c}\begin{array}{c}\text { Seed Dia. } \\
(\mathrm{mm})\end{array} \\
\text { MS }\end{array}$} & \multirow{2}{*}{$\begin{array}{c}\begin{array}{c}\text { Hardnes } \\
s^{\mathbf{a}} \text { (unit) }\end{array} \\
\text { MS }\end{array}$} & \multicolumn{2}{|c|}{$\begin{array}{c}\text { Flour Yield } \\
\qquad(\mathrm{g} / \mathrm{kg})\end{array}$} & \multicolumn{2}{|c|}{$\begin{array}{c}\text { Flour Protein } \\
(\%)\end{array}$} & \multirow{2}{*}{$\begin{array}{c}\begin{array}{c}\text { Mix. Time } \\
(\mathrm{min})\end{array} \\
\text { MS }\end{array}$} & \multirow{2}{*}{$\begin{array}{c}\text { Mix. Tol. } \\
(0-7) \\
\text { MS }\end{array}$} \\
\hline & df & MS & df & MS & df & MS & & & df & MS & df & MS & & \\
\hline Environment (E) & 8 & $45657943^{* * * \mathrm{c}}$ & 6 & $971.88 * *$ & 2 & $164.66 * *$ & 0.21 ** & $295.40 * *$ & 8 & $93879.9^{* *}$ & 8 & $87.58 * *$ & $37.10 \% *$ & $6.18^{* * *}$ \\
\hline Genotype (G) & 31 & 436800 & 31 & $12.61^{* *}$ & 31 & $18.36^{* * *}$ & $0.04 * *$ & $239.10^{* *}$ & 31 & $1472.3^{* * *}$ & 31 & $1.44^{*}$ & $2.65^{* *}$ & $2.79^{\text {*** }}$ \\
\hline Check cultivars $(\mathrm{C})$ & 4 & 566415 & 4 & 4.99 & 4 & $40.45 * *$ & $0.06 * *$ & $42.03 * *$ & 4 & 441.68 & 4 & 1.01 & $2.31^{* *}$ & 1.18 \\
\hline Mixing tolerant lines (L) & 26 & $406696^{*}$ & 26 & $12.48 * *$ & 26 & $15.33 * *$ & $0.04 * *$ & $318.45 * *$ & 26 & $1736.94 * *$ & 26 & $1.76^{* *}$ & $3.73 * *$ & $3.43^{* *}$ \\
\hline C vs. L & 1 & 701077 & 26 & $1220.74 * *$ & 1 & $85.49 * *$ & $0.21 * *$ & 0.03 & 1 & $4446.04 * *$ & 1 & $4.59 * *$ & 8.81 ** & 1.75 \\
\hline $\mathrm{E} \times \mathrm{G}$ & 248 & 309614 & 168 & 3.16 & 58 & $4.91 * *$ & $0.02 * *$ & $21.04 * *$ & 243 & 271.0 & 248 & $0.92 * *$ & $0.75^{* *}$ & $0.88^{* * *}$ \\
\hline $\mathrm{E} \times \mathrm{C}$ & 32 & 163863 & 15 & 3.56 & 8 & $3.14 * *$ & $0.01 *$ & $12.65 * * *$ & 28 & 339.99 & 32 & $0.80^{*}$ & 0.55 & 0.81 * \\
\hline $\mathrm{E} \times \mathrm{L}$ & 208 & 287993 & 148 & 3.13 & 48 & $5.11 * *$ & $0.02 * *$ & $17.55 * *$ & 208 & 253.96 & 208 & $0.91^{* *}$ & $0.76^{* * *}$ & $0.85^{\text {क*⿻一⿰冫⿰亅⿱丿丶丶 }}$ \\
\hline $\mathrm{E} \times(\mathrm{C}$ vs. $\mathrm{L})$ & 8 & $1454768 * *$ & 5 & 2.32 & 2 & $6.48 * *$ & $0.04 * *$ & $35.45 * *$ & 7 & 502.01 & 8 & $2.00 * *$ & $1.48 * *$ & 1.79 ** \\
\hline Pooled error & 279 & 256016 & 35 & 4.12 & 59 & 1.08 & 0.005 & 3.59 & 124 & 366.2 & 93 & 0.47 & 0.39 & 0.51 \\
\hline $\mathrm{CV} \%$ & & 17.88 & & 2.74 & & 3.37 & 3.05 & 3.86 & & 3.42 & & 5.46 & 14.96 & 18.84 \\
\hline Genotype means & & 2845 & & 75.1 & & 30.6 & 2.3 & 49 & & 558.0 & & 12.6 & 4.2 & 3.8 \\
\hline
\end{tabular}

a 1,000 kernel weight (TKW), seed diameter, and kernel hardness from SKCS 4100 analysis.

${ }^{b}$ Block (E) was considered in the ANOVA model but not reported in this table.

c *** Significant at $P=0.05$ and $P=0.01$, respectively. 
regression were tested for significance by an F-test. Regression coeflicients for genotypes were compared among the lines by a two-tailed t-test.

\section{RESULTS AND DISCUSSION}

\section{Agronomic Performance Traits}

Significant differences among all of the genotypes were observed lor all traits except grain yield. The $\mathrm{G} \times \mathrm{E}$ interaction was also significant for most agrononic traits except grain yield and grain volume weight (Table I). From the partitioned analysis of variance, check cultivars differed for $1,000 \mathrm{kernel}$ weight and seed diameter: however they did not differ for grain yield and grain volume weight. Mixing tolerant lines differed for all agronomic trats. Hence, genelic variation for agronomic traits existed among the mixing tolerant lines. The single degree of freedom contrasts of check cultivars versus mixing tolerant genotypes indicated the check cultivats and mixing tolerant genotypes were similar for grain yicld, but check cultivars had lower grain volume weight and greater $1,0(0)$ kernel weight and seed diameter. The interactions of environment with check cultivars and environment with mixing tolerant lines were significant for 1,000 kernel weight and seed diameter but not for grain yicld and grain volume weight. These results indicated that genetic differences among check cultivars and mixing tolerant lines were similar across enviromments for grain yield and grain volume weight. However, their respective envirommental responses were not similar for 1,000 kernel weight and seed diameter. The environment $\times$ (check cultivars vs. mixing tolerant lines) interaction was significant for grain yield, 1,000 kemel weight, and seed diameter but not for grain volume weight. The significant interactions were mainly due to changes in magnitude, not reversals in order; hence, we will discuss the genotypic means averaged over environments.

The mixing tolerant genotypes had similar grain yicld $(2,845$ $\mathrm{kg} / \mathrm{ha})$ as check cultivars $(2,749 \mathrm{~kg} / \mathrm{ha})$. Mean grain yicks of mixing tolerant genotypes across environment ranged from 2,608 to $3,186 \mathrm{~kg} / \mathrm{ha}$ whereas grain yields of check cultivars ranged from 2,455 to $2,928 \mathrm{~kg} / \mathrm{ha}$. NE96539 (3,010 $\mathrm{kg} / \mathrm{ha}), \mathrm{NE96545}$ (3010 kg/ha), NE96408 (3,032 kg/ha), NE96440 (3,003 kg/ha), NE96456 $(3,068 \mathrm{~kg} / \mathrm{ha})$, and NE96587 $(3,186 \mathrm{~kg} / \mathrm{ha})$ were the best-yielding genotypes among the mixing tolerant genotypes. NE96587 was superior to all check cultivars except Siouxland (Table II). Mean grain volume weights of mixing tolcrant genotypes ranged from 72.0 to $78.2 \mathrm{~kg} / \mathrm{hL}$. However, mean grain volume weights of check cultivars were low compared with mixing tolerant lines and ranged from 65.3 to $68.2 \mathrm{~kg} / \mathrm{hL}$. NE96539 (78.2 $\mathrm{kg} / \mathrm{hL}$ ), NE96545 (77.2 kg/hL), and NE96587 (74.7 kg/hI) were supcrior to check cultivars for grain volume weight. Mean $1,0(0)$ kernel weight of mixing tolerant genotypes ranged from 27.1 to $32.4 \mathrm{~g}$. Means of check cultivars ranged from 29.3 to $35.7 \mathrm{~g}$. NE96545 (32.3 g) and NE96683 (32.9 g) were the highest in performance and superior to Siouxland, Centura, and Arapahoe for

TABLE II

Genotype Mean Values for Agronomic Performance and Quality Characterisitics of 32 Hard Red Winter Wheats Grown Across Nine Environments in 1997 and 1998 Crop Seasons in Nebraska

\begin{tabular}{|c|c|c|c|c|c|c|c|c|c|}
\hline Genotype & $\begin{array}{l}\text { Grain } \\
\text { Yield } \\
\text { (kg/ha) }\end{array}$ & $\begin{array}{c}\text { Grain } \\
\text { Volume Wt } \\
(\mathrm{kg} / \mathrm{hL})\end{array}$ & $\begin{array}{c}1,000 \\
\text { Kernel Wt } \\
(\mathrm{g})\end{array}$ & $\begin{array}{c}\text { Seed } \\
\text { Diameter } \\
(\mathrm{mm})\end{array}$ & $\begin{array}{c}\text { Kernel } \\
\text { Hardness } \\
\text { (SKCS unit) }\end{array}$ & $\begin{array}{l}\text { Flour } \\
\text { Yield } \\
(\mathrm{g} / \mathrm{kg})\end{array}$ & $\begin{array}{l}\text { Flour } \\
\text { Protein } \\
(\%)\end{array}$ & $\begin{array}{l}\text { Mixing } \\
\text { Time } \\
\text { (min) }\end{array}$ & $\begin{array}{c}\text { Mixing } \\
\text { Tolerance } \\
(0-7 \text { scale })\end{array}$ \\
\hline \multicolumn{10}{|c|}{ Check cultivars } \\
\hline Agate & 2776 & 68.2 & 35.7 & 2.5 & 46 & 571 & 12.8 & 3.5 & 3.8 \\
\hline Arapahoe & 2837 & 67.0 & 29.3 & 2.3 & 51 & 572 & 12.8 & 4.2 & 3.6 \\
\hline Centura & 2456 & 65.3 & 30.8 & 2.3 & 52 & 565 & 13.1 & 4.3 & 4.0 \\
\hline Scout 66 & 2751 & 67.9 & 35.5 & 2.5 & 46 & 582 & 13.2 & 3.2 & 3.7 \\
\hline Siouxland & 2926 & 66.9 & 32.1 & 2.4 & 50 & 572 & 12.4 & 3.9 & 3.2 \\
\hline Mean values & 2749 & 67.1 & 32.7 & 2.4 & 49 & 572 & 12.9 & 3.8 & 3.7 \\
\hline \multicolumn{10}{|c|}{ Mixing tolerant lines } \\
\hline NE9640I & 2616 & 74.6 & 27.1 & 2.1 & 54 & 556 & 12.3 & 4.8 & 3.5 \\
\hline NE96406 & 2608 & 76.0 & 31.3 & 2.3 & 16 & 518 & 13.2 & 5.5 & 5.1 \\
\hline NE96408 & 3032 & 74.7 & 31.3 & 2.3 & 47 & 557 & 11.8 & 4.0 & 3.4 \\
\hline NE964II & 2826 & 76.6 & 30.8 & 2.3 & 47 & 568 & 12.6 & 4.0 & 3.5 \\
\hline NE96412 & 2668 & 73.9 & 32.4 & 2.3 & 51 & 550 & 12.6 & 3.9 & 3.7 \\
\hline NE96440 & 3003 & 75.1 & 30.1 & 2.2 & 47 & 561 & 12.8 & 4.5 & 4.4 \\
\hline NE96446 & 2978 & 75.4 & 30.3 & 2.3 & 53 & 555 & 12.7 & 3.5 & 3.4 \\
\hline NE96456 & 3068 & 74.4 & 29.3 & 2.3 & 52 & 555 & 12.3 & 4.3 & 3.9 \\
\hline NE96457 & 2848 & 73.7 & 27.7 & 2.1 & 54 & 559 & 12.1 & 4.2 & 4.3 \\
\hline NE96459 & 2645 & 75.0 & 29.6 & 2.2 & 54 & 543 & 12.9 & 4.1 & 4.3 \\
\hline NE96469 & 2925 & 74.9 & 29.9 & 2.3 & 53 & 573 & 12.3 & 3.9 & 3.7 \\
\hline NE96500 & 2867 & 76.8 & 32.3 & 2.4 & 41 & 560 & 12.8 & 3.7 & 3.6 \\
\hline NE96507 & 2690 & 73.9 & 31.5 & 2.3 & 50 & 564 & 12.5 & 4.6 & 4.3 \\
\hline NE96539 & 3010 & 78.2 & 29.5 & 2.3 & 59 & 566 & 12.3 & 3.4 & 3.1 \\
\hline NE96540 & 2869 & 75.9 & 32.1 & 2.3 & 51 & 565 & 12.5 & 4.1 & 3.9 \\
\hline NE96542 & 2742 & 74.9 & 29.8 & 2.3 & 38 & 540 & 12.5 & 4.6 & 4.2 \\
\hline NE96545 & 3010 & 77.2 & 32.3 & 2.4 & 49 & 552 & 12.8 & 4.4 & 4.3 \\
\hline NE96564 & 2731 & 74.5 & 28.5 & 2.2 & 55 & 564 & 12.7 & 4.3 & 3.9 \\
\hline NE96572 & 2755 & 73.7 & 33.0 & 2.4 & 47 & 570 & 12.5 & 4.5 & 3.7 \\
\hline NE96583 & 2882 & 75.9 & 32.4 & 2.4 & 49 & 558 & 13.2 & 4.5 & 5.3 \\
\hline NE96587 & 3186 & 74.7 & 28.2 & 2.2 & 51 & 563 & 12.0 & 5.0 & 3.8 \\
\hline NE96588 & 2952 & 73.4 & 28.6 & 2.2 & 51 & 572 & 11.8 & 5.6 & 3.3 \\
\hline NE96610 & 2769 & 74.6 & 31.7 & 2.3 & 55 & 553 & 12.4 & 3.7 & 3.2 \\
\hline NE96626 & 2771 & 74.4 & 31.9 & 2.4 & 58 & 552 & 12.2 & 4.2 & 3.3 \\
\hline NE96653 & 2715 & 75.6 & 28.5 & 2.2 & 48 & 566 & 12.3 & 3.9 & 3.6 \\
\hline NE96667 & 2782 & 75.6 & 33.2 & 2.4 & 43 & 568 & 13.0 & 3.6 & 3.5 \\
\hline NE96683 & 2872 & 72.0 & 32.9 & 2.4 & 53 & 548 & 13.0 & 3.5 & 3.6 \\
\hline Mean values & 2845 & 75.1 & 30.6 & 2.3 & 49 & 558 & 12.6 & 4.2 & 3.8 \\
\hline LSD $(0.05)^{a}$ & 332.0 & 2.1 & 1.4 & 0.1 & 2.5 & 15.0 & 0.6 & 0.50 & 0.6 \\
\hline
\end{tabular}

"Least significant differences $(P=0.05)$. 
1,000 kernel weight. The mixing tolerant genotypes had seed diameters $(2.3 \mathrm{~mm})$ similar to that of the check cultivars $(2.4$ $\mathrm{mm})$. Seed diameters of Agate and Scout $66(2.5 \mathrm{~mm})$ had the highest value compared with other genotypes tested in this study. However, NE96583, NE96683, NE96667, NE96626, NE96572, NE96545, and NE96.500 seed diameters $(2.4 \mathrm{~mm})$ were superior to those of Arapahoe and Centura and equal to Siouxland. These results indicate that the potential exists for improving grain yicld and other agronomic traits of mixing tolerant genotypes. These genotypes can also be used as parents in breeding programs for deriving genotypes with higher performance compared with check cultivars.

\section{End-Use Quality Traits}

The effects of environments and genotypes were significant for all end-use quality traits. The $\mathrm{G} \times \mathrm{E}$ interaction was also significant for most traits except flour yicld (Table I). From the partitions of the genotypes, nonsignificant differences were found among check cultivars for each trait except mixing time and kernel hardness. End-use quality uniformity is considered very desirable by flour millers who source wheat grain from different cultivar distribution. Mixing tolerant genotypes showed highly significant variation for all end-use quality traits. The single degree of freedom contrasts of check cultivars versus mixing tolerant genotypes indicated the check cultivars and mixing tolcrant genotypes were similar for hardness and mixing tolerance but significantly different for the other end-usc quality traits. The check cultivars had significantly higher flour protem concentrations and flour yield, but shorter mixing times than the mixing tolerant cultivars.

The environment is a critical variable in the expression of the quality traits (Peterson et al 1992; Fenn et al 1994; Graybosch et al 1996). In our study, the interaction of the check cultivars with environment was significant for kernel hardness, flour protein content, and mixing tolerance but was not significant for flour yield, and mixing time. Differences in environmental response of these genotypes to mixing tolerance, flour protein content, and kernel hardness were due mainly to changes in magnitude and small reversals in order. These results indicated that genetic differences among check cultivars were relatively similar across environments for flour yield and mixing time. However, response to the environment was different for kernel hardness, llout protein content, and mixing tolerance. The results for lour protein content in this study agree with results reported earlier by Moreno-Sevilla et al (1995). However, they found similar response to environment for mixing time and mixing tolerance, which maly be due to population structure (IBI/IRS genotypes). Our results also confirm results of Peterson et al (1992), who reported that environments had remarkable effects on variation in kernel hardness. flour protein, and mixing chatracteristics.

The $G \times E$ interaction of mixing tolerant lines was significant for all traits except flour yield, indicating that they responded similarly to environment for flour yicld but were different for the other end-use quality trats. 'The $\mathrm{E} \times \mathrm{C}$ vs. L, interation was also significant for all end-use quality traits except for flour yick. Hence, the check cultivars and mean of mixing tolerant lines responded similarly to the environment for llour yield characteristics. The $\mathrm{G} \times \mathrm{E}$ interaction was duc to changes in magnitude not reversals in order.

Flour protein concentrations of NF96406 (1.3.2\%) and NF:96.58.3 $(13.3 \%)$, genotypes that had shorter mixing time seores and mixing tolerance values, were higher than all check cultivars except Scout $66(13.2 \%)$ which is one of the best performing genotypes for both flour protein and flour yield. Mixing time and

TABLE III

Univariate Probabilities for Quality Characterisitics Values Falling Within Acceptable Limits ${ }^{\mathrm{a}}$

\begin{tabular}{|c|c|c|c|c|c|c|}
\hline Genotype & Flour Protein & Mixing Time & Mixing Tolerance & Flour Yield & Kernel Hardness & All Traits \\
\hline Agate & 0.67 & 0.44 & 0.89 & 0.89 & 0.33 & 0.11 \\
\hline Arapahoe & 0.56 & 0.56 & 1.00 & 0.89 & 0.33 & 0.00 \\
\hline Centura & 0.67 & 0.78 & 1.00 & 0.78 & 0.33 & 0.11 \\
\hline Scout66 & 0.78 & 0.33 & 1.00 & 0.89 & 0.33 & 0.11 \\
\hline Siouxland & 0.67 & 0.67 & 0.67 & 0.89 & 0.33 & 0.11 \\
\hline NE96401 & 0.44 & 0.56 & 1.00 & 0.89 & 0.33 & 0.00 \\
\hline NE96406 & 0.67 & 1.00 & 1.00 & 0.67 & 0.00 & 0.00 \\
\hline NE96408 & 0.11 & 0.44 & 1.00 & 0.89 & 0.33 & 0.00 \\
\hline NE96411 & 0.56 & 0.67 & 0.89 & 1.00 & 0.33 & 0.11 \\
\hline NE96412 & 0.44 & 0.78 & 1.00 & 0.89 & 0.33 & 0.00 \\
\hline NE96440 & 0.67 & 0.78 & 0.89 & 1.00 & 0.33 & 0.11 \\
\hline NE96446 & 0.56 & 0.44 & 1.00 & 0.78 & 0.33 & 0.00 \\
\hline NE96456 & 0.56 & 0.78 & 1.00 & 0.78 & 0.33 & 0.00 \\
\hline NE96457 & 0.33 & 0.89 & 1.00 & 0.78 & 0.33 & 0.11 \\
\hline NE96459 & 0.78 & 0.67 & 1.00 & 0.67 & 0.33 & 0.00 \\
\hline NE96469 & 0.44 & 0.67 & 1.00 & 0.89 & 0.33 & 0.00 \\
\hline NE96500 & 0.56 & 0.56 & 0.89 & 0.89 & 0.33 & 0.11 \\
\hline NE96507 & 0.56 & 0.78 & 1.00 & 1.00 & 0.33 & 0.11 \\
\hline NE96539 & 0.33 & 0.44 & 0.78 & 1.00 & 0.33 & 0.00 \\
\hline NE96540 & 0.44 & 0.56 & 1.00 & 1.00 & 0.33 & 0.11 \\
\hline NE96542 & 0.56 & 1.00 & 1.00 & 0.78 & 0.33 & 0.11 \\
\hline NE96545 & 0.67 & 0.78 & 1.00 & 0.78 & 0.33 & 0.11 \\
\hline NE96564 & 0.67 & 0.67 & 1.00 & 1.00 & 0.33 & 0.11 \\
\hline NE96572 & 0.44 & 0.67 & 1.00 & 1.00 & 0.33 & 0.11 \\
\hline NE96583 & 0.67 & 0.78 & 1.00 & 1.00 & 0.33 & 0.11 \\
\hline NE96587 & 0.22 & 1.00 & 1.00 & 0.78 & 0.33 & 0.00 \\
\hline NE96588 & 0.22 & 0.89 & 1.00 & 1.00 & 0.33 & 0.00 \\
\hline NE96610 & 0.33 & 0.56 & 0.78 & 0.78 & 0.33 & 0.00 \\
\hline NE96626 & 0.44 & 0.67 & 0.89 & 0.78 & 0.22 & 0.00 \\
\hline NE96653 & 0.56 & 0.67 & 0.89 & 0.89 & 0.22 & 0.00 \\
\hline NE96667 & 0.67 & 0.44 & 0.89 & 1.00 & 0.22 & 0.11 \\
\hline NE96683 & 0.56 & 0.33 & 0.89 & 0.78 & 0.22 & 0.00 \\
\hline
\end{tabular}

: Values chosen for upper and lower limits were flour protein 12.5-19.0\%, mixing time 3.5-8.0 min, mixing tolerance 2.5-7.0 (on a 0-7 scale), flour yield 500-650 $\mathrm{g} / \mathrm{kg}$, kernel hardness 25-65 SKCS units.

b Multivariate probabilities of all traits for 32 genotypes grown in nine environments. 
mixing tolerance values of Agate were 3.5 and $3.8 \mathrm{~min}$, respectively. Mixing time values of NE96457 (4.2 min), Nl:96459) (4.1 min). Nl 968.3 (4.5 min), and NE96683 (3.5 min) genotypes were shorter than mixing tolerance values $(4.3,4.3,5.3$, and 3.6, respectively) across all environments. However, mixing time values of the remaining genotypes in this study were higher than mixing lolerance values (lable II), as was commonly found in previous research (Bacnziger et al 2001 ). Hence, our prediminary sereen, which identilied 27 genotypes with mixing tolerance values that were barger than the mixing time values, was only patially eflective $(4 / 27=15 \%$ were correctly identified, $85 \%$ were incorredly identilied) in identifying genotypes with these characteristics. Iividently, the environment alfects these traits and the relative magnitudes.

An important question is whether flour protein content could explain the mixing characteristics. To answer this question, flour protein content wats treated as a covariate of mixing time and mixing tolerance in analyses of covariance. The effect of the flour protein content covariate was signilicant $(P<0.05)$ for mixing lime; however, it was nonsignificant for mixing tolerance. These results indicated that mixing time was affected by flour protein content, whereas, mixing tolerance wals not.

Univariate and multivariate approaches were conducted to determine the value of our initial sereen using sample proportion of enviromment where values of a cultivar trait fell within a specified limits (liskridge and Mumm 1992; Isskridge el al 1994). Univariate probability values were $(0.11-1.0$ and reflected the probability of traits falling within the established absolute acceptability limits (lable III). NE: 96457 and NF96459, which had shorter mixing line than mixing lolerance, showed the highest probability ol meeting absolute acceptability standards for mixing tolerance. NI:96583, which is also identified as having shorter mixing time values, had higher probability for mixing time and mixing tolerance $(P=0.78$ and $P=1.0$, respectively). These values indicaled that the probability of identifyng acceptable end-use quality in an initial screen when grown at a single location is similat to results firm multiple environments for dough mixing characteristics. Univaltite probabilities for mixing tolerant lines, which were originally selected on the basis of shorter mixing time values, also had a probability of equaling or exeeeding mixing time of the check cullivars. These values reflected the high probalsility of achieving aceeptable quality for individual traits and all traits when the lines are grown in a single environment that is representative of future testing environments (liskridge el al 1994). Overall, we identilied 12 mixing tolerant lines (NE96411, NE96440, NE96457, NE96500, NI:96507, NI99640, NE96542, NE96545, NE96564, NE96572, NI:96583, and N1:96667), which had multivariate probabilities of equaling or exceeding the check cultivars for all end-use quality traits. In addlition, every mixing tolerant line had mixing time and tolerance values $>3$ and would be considered as aceeptable. Hence, our preliminary sereen stecesslully selected the genotypes with acceptable mixing time and tolerance values.

\section{Stability of Traits and Environmental Interactions}

Partitioning $G \times F$ interactions (lincar) into mixing tolerant lines (lincar), and check cultivars (lincar) showed nonsignificant differences in slope for all traits except among the mixing tolerant lines (linear) for grain volume weight (Table IV). Hence, genotypes within the mixing toleran group and within the check cultivars performed similarly from low to high environmental indices for grain yield, flour yick, flour protein, mixing time, and mixing tolerance. However, the check cultivars Scout 66 and Siouxland performed dissimilarly from one another under different environmental conditions for dough mixing characteristics (mixing time and mixing tolerance) and grain volume weight. Scout 66 and Siouxland (both had shorter mixing time values vs. mixing tolerant values) were more responsive to environments versus other check cultivars for mixing characteristics. This suggested that genotypes with shorter mixing times were generally less stable across environments. These results are contrary to lindings of Peterson et al (1992), who reported that genotypes with higher mixing time and increased mixing 1oleranee, such as Karl and Redland, were generally more responsive to environments.

There were few significant deviations from regression, indicating that agronomic and end-use quality traits generally illustrated a linear trend across environments. Nonsignificant deviations from regression also indicated most genotypes were stable for all traits tested. Regressing genotype means on an environmental index indicated that check cultivars were not environmentally sensitive, exeept Scout 66, which was highly sensitive to environments for mixing lime. The mixing tolerant genotypes differed significantly in their lincar regression coeflicients for grain volume weight. $\Lambda$ s was expected, some mixing tolerant genotypes showed more sensitivity to different environmental conditions compared with check cultivars, as indicated by differences in slope between the two sets of genotypes for grain volume weight and mixing time (Table IV). NE96683, NE96586, NE96459, and NE96457, which had been identified with mixing time scores shorter than mixing tolerance scores, had nonsignificant regression coefficients and would be considered stable for all traits tested. Crossover interactions for the elfects of genotypes for all trats tested were not significant, again indicating the significant $G \times \mathrm{I}$ was due to changes in magnitude, rather than reversals in order.

\section{CONCLUSIONS}

In conclusion, we found that previously released Agate (3.5 min and 3.8) and Scout 66 (3.2 min and 3.6) and four mixing tolerant lines, NE96457, NE96459, NE96583, and NE96683 had mixing tolerance values that were slightly greater than their mixing time values. Our preliminary sereen, which had identified 27 genotypes, was only slightly effective in identifying genotypes $(15 \%)$ that have shorter mixing time values compared with mixing tolerance values. Our initial sereen predicted aceptable cond-use quality traits very well, but the environment caused signilicant variation

TABLE IV

Linear and Nonlinear Portioning of Genotype $\times$ Environment Interactions ${ }^{\mathrm{a}}$

\begin{tabular}{|c|c|c|c|c|c|c|c|}
\hline Source & df & Grain Yield & Grain Volume Wt & Flour Yield & Flour Protein & Mixing Time & Mixing Tolerance \\
\hline Genotypes (G) & 31 & 223851 & $27.7 * * b$ & $1325.0 * *$ & $1.2 *$ & $2.2 * *$ & 2.3 *** \\
\hline Environment (E) (linear) & 1 & $184231336 * \% \mathrm{~b}$ & $1318.9^{* *} *$ & $484181 * *$ & $609.9^{* * *}$ & $182.1 * *$ & $26.2 * *$ \\
\hline $\mathrm{G} \times \mathrm{E}$ (linear) & 31 & 89926 & $101.2 * *$ & 142.1 & 0.8 & 0.6 & 0.8 \\
\hline Check cultivars $(C) \times E$ & 4 & 65039 & 4.2 & 174.6 & 0.5 & 0.6 & 0.8 \\
\hline $\begin{array}{l}\text { Mixing tolerant lines }(\mathrm{L}) \\
\times \mathrm{E}\end{array}$ & 26 & 84786 & $25.9 * *$ & 138.6 & 0.8 & 0.5 & 0.7 \\
\hline$(\mathrm{C}$ vs. $\mathrm{L}) \times \mathrm{E}$ (linear) & 1 & 323114 & $514.0 * *$ & 174.4 & 0.2 & $3.2 *$ & 1.8 \\
\hline Pooled deviations & 224 & 161033 & $13.3^{\mathrm{c}}$ & 217.7 & 0.8 & 0.6 & 0.8 \\
\hline
\end{tabular}

a Mean square values for grain yield, grain volume weight, flour yield, flour protein, mixing time, and mixing tolerance across nine environments in the $1997-98$ crop seasons in Nebraska.

b *,** Significant at $P=0.05$ and $P=0.01$, respectively.

${ }^{c}$ Degrees of freedom for grain volume weight (pooled deviations) is 209. 
for both mixing time and mixing tolerance. Hence, to accurately estimate end-use quality traits of a genotype, multiple-environments testing is needed. This is routinely done with multiyear testing (Baenziger et al 2001). Environmentally sensitive genotypes determined by partitioning the $\mathrm{G} \times \mathrm{E}$ interaction were detected for grain volume weight and mixing time and was caused by changes in magnitude and not reversals in order. Because there was significant variation among the genotypes in response of quality traits to environments, we evaluated consistency of performance regarding upper limits of industry acceptability. Univariate and multivariate approach showed that end-use quality values of mixing tolerant lines fell within acceptable end-use quality limits. Stability of agronomic and end-use quality characteristics across enviromments is important to brecders and the milling and baking industry to enhance product consistency. With the probability approach, NE96583 and NE96457, which had mixing tolerance scores higher than mixing time scores showed a high probability of mantaining acceptable quality standards across environments and a high level of consistency when measured in relation to industry quality needs.

\section{LITERATURE CITED}

American Association of Cereal Chemists. 2000. Approved Methods of the AACC, loth ed. The Association: St. P'aul, MN.

Baenziger, P. S., Shelton, D. R., Shipman, M. J., and Graybosch, R. A.
2001. Breeding for end-use quality: Reflections on the Nebraskat expcrience. Huphytica 119:95-100).

Bushuk, W. 1998. Interactions: The keys to cercal quality. Ant. Assoce. Cereal Chem.: St. l'aul, MN.

Docrry, W. 1995. Baking Tochnology. Vol. I. Am Insi. Baking: Manhattan, KS

Eberhart, S. A., and Russell, W. A. 1966. Stability paramelers fou comparing varictics. Crop Sci. (6:36-40).

Eskridge, K. M. and Mumm. R. I: 1992. Choosing plant cultivalts batsed on the probability of outperforming a check. Theor. Appl. (ienel. 84:49) $4-5(0)$.

Eskridge, K. M., Peterson, (. J., and Grombatcher, $\wedge ., W .199+$ Probability of the wheat guality taits falling within aceepalble linsits. Crop Sci. 34:866-869.

Graybosch, R. A., Peterson, C. J., Shelton. D. R., and Bacmpiger, P'. S 1996. Genotypic and environnental modification of wheal flour protein composition in retation to end-use cuality. (rop Sci. 36:296300 .

Paredes-1ope\%, O., and Bushuk. W. 1983. Development and undevelopment of what dough by mixing: Physicoshemical studies. Cereal Chem. 6():19-23.

Peterson, C. J. 1992. Similarities annong kest sites balsed cullivalt performance in the hard red winter wheall region. (rop) Sci. 32:9(1)7912.

Peterson, C. J., Graybosch, R. A. Baenriger, P. S., and Grombateher A. W. 1992. Gentype and environment effects on quality chantaterisises of hard red winter wheat. Crop Sci. 32:98- 10.3.

[Received December 6, 2002. Accepted January 23, 2003.] 